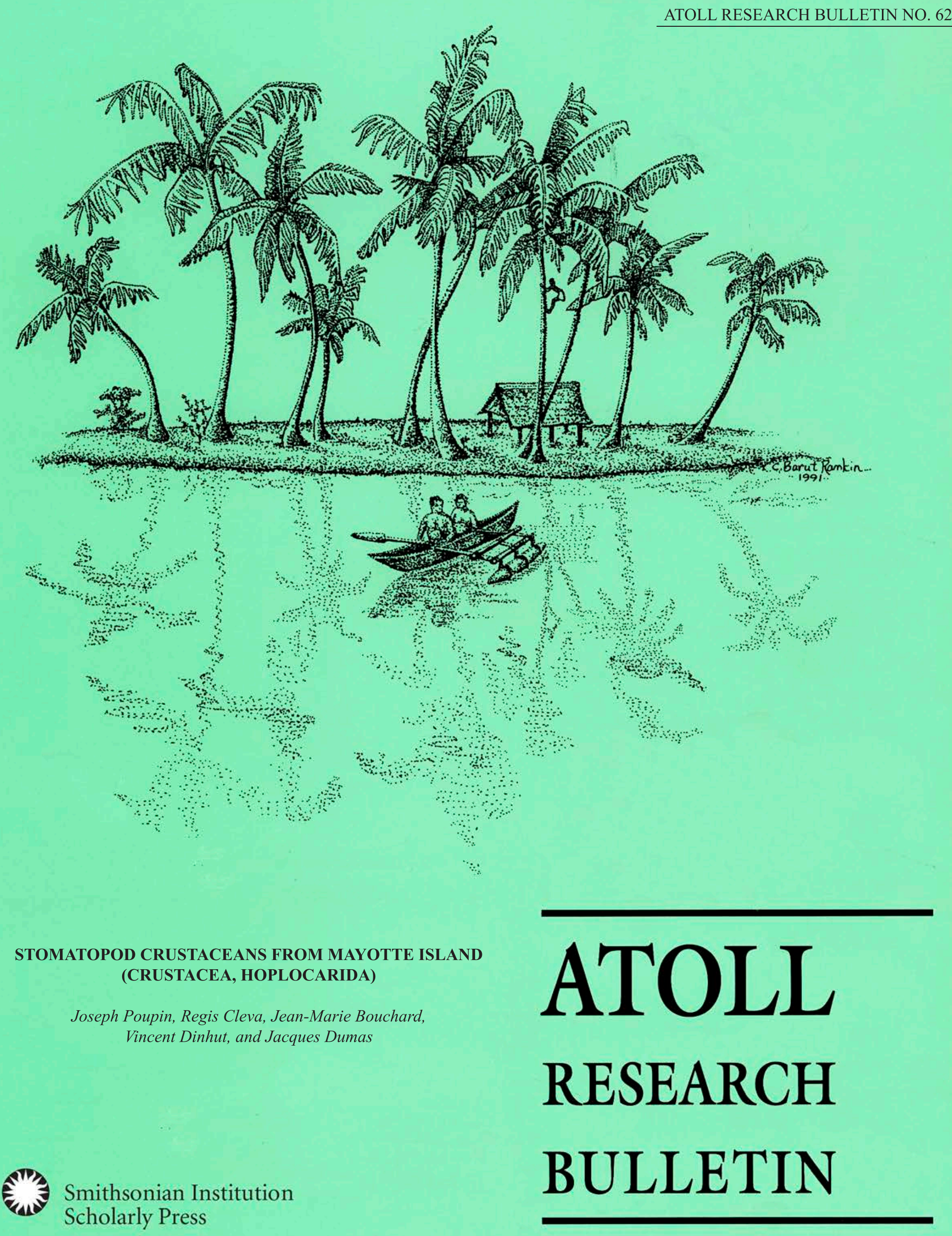




\title{
STOMATOPOD CRUSTACEANS FROM MAYOTTE ISLAND (CRUSTACEA, HOPLOCARIDA)
}

\author{
Joseph Poupin, Regis Cleva, Jean-Marie Bouchard, \\ Vincent Dinhut, and Jacques Dumas
}

Atoll Research Bulletin No. 624 • 6 June 2019

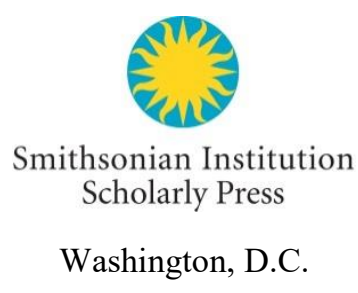


All statements made in papers published in the Atoll Research Bulletin are the sole responsibility of the authors and do not necessarily represent the views of the Smithsonian Institution or of the editors of the bulletin. Articles submitted for publication in the Atoll Research Bulletin should be original papers and must be made available by authors for open access publication. Manuscripts should be consistent with the "Author Formatting Guidelines for Publication in the Atoll Research Bulletin." All submissions to the bulletin are peer reviewed and, after revision, are evaluated prior to acceptance and publication through the publisher's open access portal, Open SI (https://opensi.si.edu).

Published by SMITHSONIAN INSTITUTION SCHOLARLY PRESS

P.O. Box 37012, MRC 957

Washington, D.C. 20013-7012

https://scholarlypress.si.edu/

The rights to all text and images in this publication are owned either by the contributing authors or by third parties. Fair use of materials is permitted for personal, educational, or noncommercial purposes. Users must cite author and source of content, must not alter or modify the content, and must comply with all other terms or restrictions that may be applicable. Users are responsible for securing permission from a rights holder for any other use.

ISSN: 0077-5630 (online) 


\section{CONTENTS}

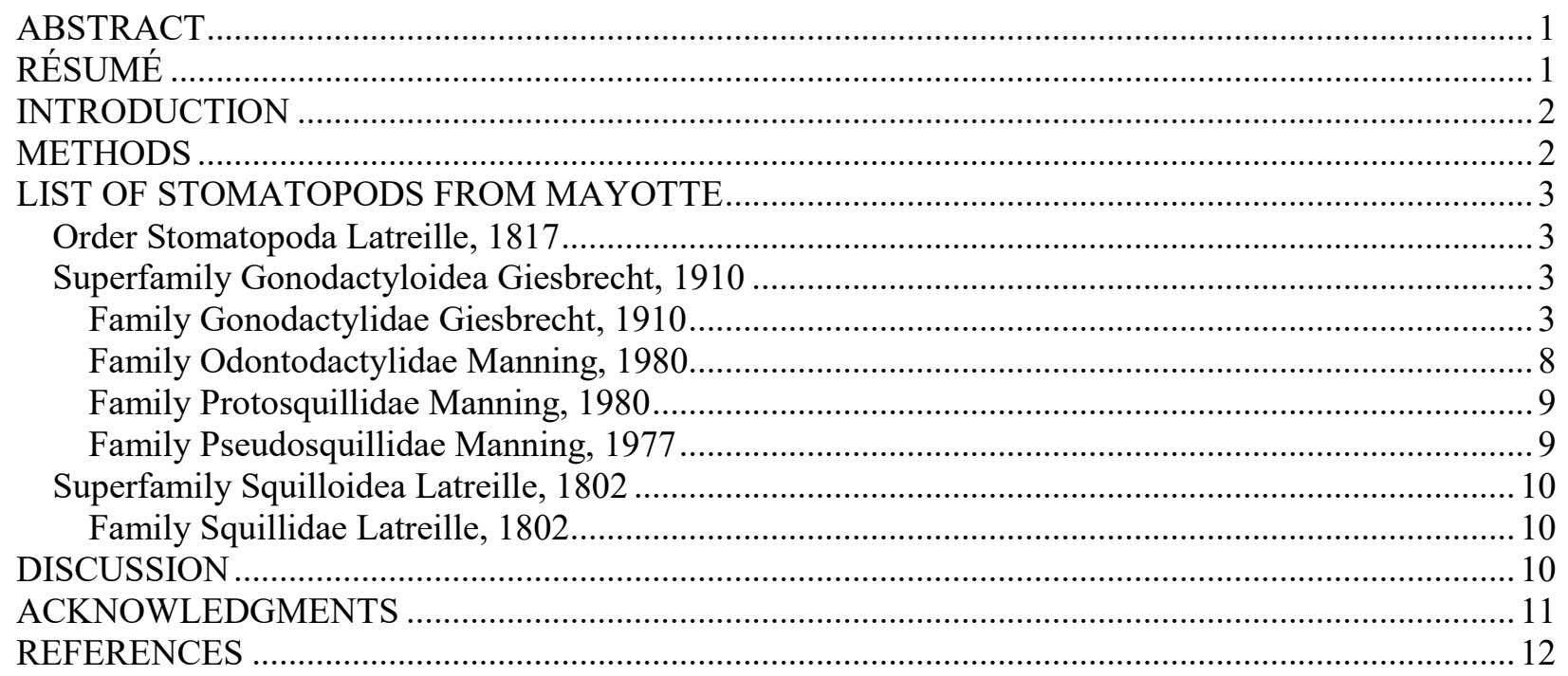





\title{
STOMATOPOD CRUSTACEANS FROM MAYOTTE ISLAND (CRUSTACEA, HOPLOCARIDA)
}

\author{
JOSEPH POUPIN ${ }^{1}$, REGIS CLEVA², JEAN-MARIE BOUCHARD ${ }^{3}$, \\ VINCENT DINHUT ${ }^{4}$ and JACQUES DUMAS ${ }^{5}$
}

\begin{abstract}
A collection of stomatopods assembled during the KUW 2009 expedition to Mayotte Island and deposited in the Muséum national d'Histoire naturelle Paris is studied with a review of previous records from Comoros and Mayotte Island. In total 14 species are recognized 3 of them being new records for this region. A brief comparison with other regions studied for stomatopods indicates that sampling is still insufficient in Comoros and Mayotte and that dozens of species remain to be inventoried in that region.

\section{RÉSUMÉ}

Une collection de stomatopodes réalisée pendant la mission KUW de 2009 sur l'île de Mayotte et déposée au Muséum national d'Histoire naturelle de Paris est étudiée, avec une revue des signalements précédents aux Comores et Mayotte. Au total 14 espèces sont reconnues, 3 d'entre elles étant de nouveaux signalements pour cette région. Une comparaison succincte avec d'autres régions étudiées pour les stomatopodes montre que les récoltes sont encore limitées aux Comores et Mayotte et que des dizaines d'espèces restent encore à inventorier dans cette région.
\end{abstract}

\footnotetext{
${ }^{1}$ École Navale du Poulmic, BCRM de Brest, CC 600 - Lanvéoc, F-29240 Brest cedex 09 (France), joseph.poupin@ecolenavale.fr, corresponding author

${ }^{2}$ Retired in 2010 from the Muséum national d'Histoire naturelle, Direction des Collections, Invertébrés, 61 rue Buffon, CP 53, 75231 Paris Cedex 05 (France), cleva.regis@orange.fr

${ }^{3}$ KUW C ${ }^{\text {ie }}$ - Kraken Underwater Works, BP 271-Kaweni, 97600 Mamoudzou, Mayotte, jmarie.bouchard@gmail.com

${ }^{4}$ ISIRUS C ${ }^{\text {ie }}$, BP 427 Kawéni, 97600 Mayotte, isirus.environnement@gmail.com

${ }^{5}$ Commission Nationale Environnement et Biologie Subaquatiques, Fédération Française d'Etude et de Sport Sous-marin, FFESSM, jacquesdumasffessm@gmail.com
} 


\section{INTRODUCTION}

This report is the fourth of a series published in Atoll Research Bulletin (ARB) to study the Crustacea (Decapoda) collected during the Kraken Underwater Works $\mathrm{C}^{\text {ie }}$ (KUW) expedition to Mayotte Island, southwestern Indian Ocean, November 1-21, 2009. This fieldwork was organized by J. -M. Bouchard, head of the KUW Cie in Mayotte, with participation of the École Navale, Brest, and the Muséum national d'Histoire naturelle (MNHN), Paris, and was targeting primarily the Crustacea (Decapoda and Stomatopoda) of the Island. Financial support was provided by the DAF (Direction de l'Agriculture et de la Forêt) of Mayotte and The Total Foundation.

Previous ARB contributions include the studies of: land, mangrove and freshwater Decapoda (Bouchard et al., 2013); Anomura (Poupin et al., 2013); and crabs (Poupin et al., 2018). More details, including map of the Island and stations prospected can be found in these contributions.

The present study focuses on the Stomatopoda collected during Mayotte KUW 2009.

\section{METHODS}

The coordinates together with a short description of the stations prospected during Mayotte KUW 2009 can be consulted in Bouchard et al. (2013). The description of marine biotopes visited and sampling techniques used in the intertidal and at sea are provided by Poupin et al. $(2013,2018)$. Stomatopods were collected in the intertidal zone by using dip nets or during scuba dives in the lagoon between $1-35 \mathrm{~m}$ with brushing of corals and blocks and by using a sediment suction pump. Out of 39 stations prospected stomatopods were captured only in the 11 stations listed herein.

St. 14: 09/11/2009; 10-12h; La Prudente bank; 12³8'50.68"S; 4458'41.93"E; 15-17 m; J. -M.

Bouchard, V. Dinhut, J. Dumas; scuba dive, sediment suction pump; sand and coral boulders.

St. 17: 10/11/2009; 11-14h; North reef; 12³4'49.93"S; 4505'52.62"E; 22 m; J. -M. Bouchard, V. Dinhut, J. Dumas; scuba dive, sediment suction pump; outer reef, sand and coral boulders.

St. 22: 12-13/11/2009; 0-24H; islet Choizil, west, Malandzamiayajou; $12^{\circ} 40^{\prime} 14.34^{\prime \prime S}$; 4502'42.66"E; 30-35 m; J. -M. Bouchard, J. Dumas, V. Dinhut; scuba dives and traps; $300 \mathrm{~m}$ far from Choizil Islet, sand and coral boulders.

St. 23: 13/11/2009; 11-13h; Choizil pass 'Patate à Teddy'; 1240'56.91"S; 4457'51.63"E; 15-30 m; J. M. Bouchard, V. Dinhut, J. Dumas; scuba dive; collapsed edge reef.

St. 25: 14/11/2009; 10-11h30; islet M'tzamboro, southern tip; 12³9'30.18"S; 45 1'38.65"E; 15-20 m; J. -M. Bouchard, V. Dinhut, J. Dumas; scuba dive; coral slope with boulders.

St. 26: 16/11/2009; 10-11h30; Mutsumbatsou reef flat; $12^{\circ} 45^{\prime} 15.60 " S ; 45^{\circ} 02^{\prime} 49.86^{\prime \prime E}$; intertidal; J. -M. Bouchard, R. Cleva, J. Dumas, V. Dinhut, J. Poupin; littoral investigation; low tide, reef flat and seagrass beds (this station also prospected previously, $03 / 08 / 2008$ by J. -M. Bouchard and 01/07/2009 by V. Dinhut).

St. 28: 17/11/09; 14h-15h30; islet Mbouini, east; 130 0'27.42"S; 45 8'16.96"E; 3-20 m; J. -M. Bouchard, V. Dinhut, J. Dumas; scuba dive, high tide, fringing reef and slope.

St. 29: 18/11/2009; 11-12h30; Ngouja hotel, Mboianatsa beach; $12^{\circ} 57^{\prime} 42.60^{\prime \prime}$; $45^{\circ} 05^{\prime} 1.30^{\prime \prime} E$; intertidal; J. -M. Bouchard, J. Dumas; littoral investigation; low tide, beach and rocky shores.

St. 31: 19/11/2009; 11-13h; Brandélé 'Plage musicale'; 1255'1.60"S; 45¹1'12.43"E; intertidal; J. Poupin, R. Cleva; littoral investigation; low tide.

St. 33: 19/11/2009; 14h30-16h30; seaside of Longoni pass; 12³6'50.76"S; 4508'58.25"E; 25 m; J. -M. Bouchard, V. Dinhut, J. Dumas; scuba dive; outer reef, gentle slope. 
St. 35: 20/11/2009; 10-12h; Surprise reef, Longoni pass; 12³8'29.95"S; 4507'45.99"E; 4-25 m; J. -M.

Bouchard, V. Dinhut, J. Dumas; scuba dive; outer reef slope.

Two large stomatopod species, not collected during Mayotte KUW 2009, have been also included in the present list because they were recognized confidently on under water photographs examined during this work. Older collections of stomatopods from Mayotte (Manning, 1968; Ahyong, 1998; Ahyong et al., 2000) were mostly made by L. S. Kornicker between 1958-1971 (including Anton Bruun Cruise 9, IIOE, 24 November 1964) and A. Crosnier between 1959-196, with specimens deposited in USNM and/or MNHN. Fourmanoir (1955) had also reported two species from the Comoros Islands.

The length of specimens examined is the total length (TL in $\mathrm{mm}$ ) measured from the apex of the rostral plate to the apices of the submedian teeth of the telson. Other abbreviations used are: AS, abdominal somite; ARB, Atoll Research Bulletin; BIORECIE, French research program 2011-2013 'Biodiversité, ressources et conservation des récifs coralliens dans le SO Océan Indien, Iles Eparses'; det., determined by; IO, Indian Ocean; IP, Indo-Pacific; IWP, Indo-West Pacific; juv., juvenile; KUW, Kraken Underwater Works Cie; MNHN, Muséum national d'Histoire naturelle, Paris; pers. comm. , personal communication; s.l., sensu lato; sp./spp., specimen/s; St., Station; TS, thoracic somite; USNM, United States National Museum; WA, Western Atlantic; WIO, Western Indian Ocean.

The taxonomy of the list follows Ahyong (2001). The determinations were made at the École navale by the senior author using keys and illustrations in Manning (1995) and Ahyong (2001). No comparative specimens were examined. All specimens are deposited in the MNHN collection (numbers MNHN-IU2013-7244 to 7259). The geographic distribution of the species is from Müller (1994) updated in Manning (1995) and Ahyong (2001).

\title{
LIST OF STOMATOPODS FROM MAYOTTE
}

\author{
Order Stomatopoda Latreille, 1817
}

\author{
Superfamily Gonodactyloidea Giesbrecht, 1910
}

Family Gonodactylidae Giesbrecht, 1910

\section{Gonodactylaceus falcatus (Forskål, 1775) (Figure 1A)}

Gonodactylus falcatus - Manning, 1968: 46, Mayotte (coll. L. S. Kornicker, St. LK-39, Anton Bruun Cruise 9, 24 November 1964, reef, 1 female TL 21.1 mm, USNM).

DisTRIBUTION - Widely distributed in the IWP. Red Sea, Tanzania, Mayotte, South Africa to Japan, Hawaii, French Polynesia. Usually intertidal, to $50 \mathrm{~m}$ in Manning (1968).

REMARK - This species was recently reported in the region, $550 \mathrm{~km}$ southwest of Mayotte at Juan de Nova Island (Poupin, 2016: 49, 1 male, TL 39.2 mm, MNHN-IU-2013-16069). The color pattern of Juan de Nova specimen is illustrated together with G. ternatensis on Figure 1. Ahyong (2001) indicates that color in life is highly polymorphic in G. falcatus and that it 'can change dramatically between moults and differs according to habitat'.

Gonodactylaceus ternatensis (de Man, 1902) (Figure 1B)

MATERIAL EXAMINED - Mission KUW November 2009. St. 25, 1 ?male juvenile TL 15.0 mm, MNHN-IU-2013-7248.

DiSTRIBUTION - Mayotte (first record), Cocos-Keeling Islands, eastern Australia, Andaman Sea, Thailand, Vietnam, Indonesia, southern China to Samoa. Mayotte is a noticeable range extension to WIO, to be confirmed by collections of additional specimens (see Remark). 
REMARK -Fresh coloration of this small specimen matches well with the color plate of $G$. ternatensis in Manning (1995, pl. 1) including the red posterior margins of the thoracic and abdominal somites, the bright blue A2 scale, and the bright blue distal segment of uropodal exopod. The specimen examined differs, however, from typical G. ternatensis by shape of rostral plate with convex anterior margin (straight of faintly concave in G. ternatensis typical) and telson knob faintly bilobed (not typically bilobed in $G$. ternatensis). It is relatively small (TL $15.0 \mathrm{~mm}$ ), to be compared with sizes to 75-87 mm indicated in Ahyong (2001), which can account for these slight morphological variations. Ahyong (2001) has also noticed that the shape of the knob of telson show variation being usually undivided but sometimes 'indented dorsally, giving a bilobed appearance'. The specimen was first considered as a juvenile female because no penes can be seen. Its coloration is, however, that of the male as illustrated in Manning (1995, pl. 1) with bright blue on A2 scale and distal segment of uropodal exopod (in females these parts are yellow; Manning, 1995, pl. 2). It is thus probable that it is a male juvenile with penes so short (bud-like) that they cannot be seen.

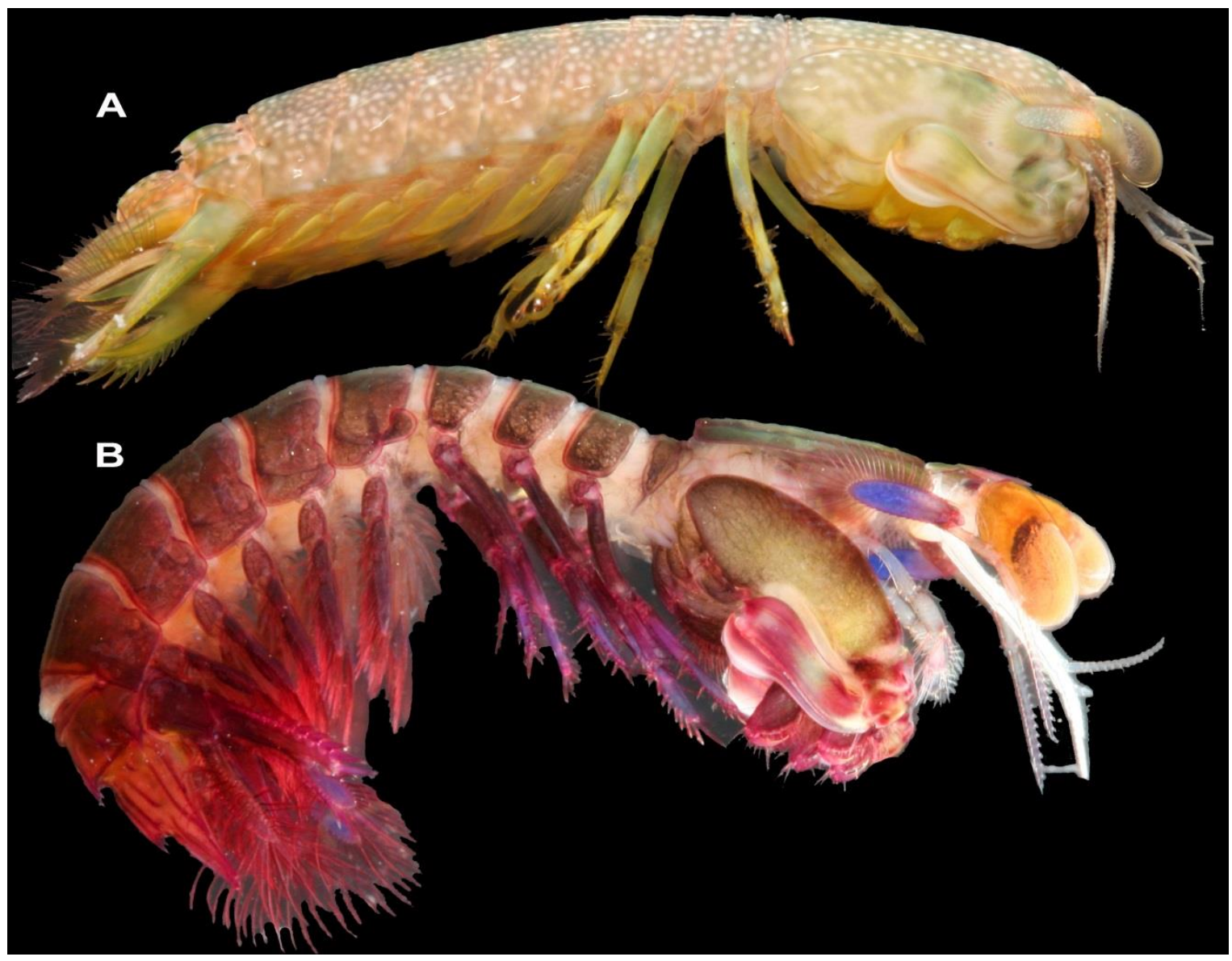

Figure 1. Color pattern of two sibling species. A) Gonodactylus falcatus, Juan de Nova, 1 male, TL 39.2 mm, MNHN-IU-2013-16069. B) Gonodactylaceus ternatensis, Mayotte, 1 ?male juvenile TL 15.0 mm, MNHN-IU-2013-7248. 
Gonodactylellus affinis (De Man, 1902) (Figure 2A)

Gonodactylus segregatus - Manning, 1968: 51, fig. 16 Mayotte (intertidal, coll. A. Crosnier, September 1959, 1 female TL 22.9 mm, USNM). - Gonodactylus chiragra var. segregatus Lanchester, 1903 currently accepted as Gonodactylellus affinis.

MATERIAL EXAMINED - Mission KUW November 2009. St. 14, 1 male TL 21.5 mm, 1 female TL 14.9 mm, MNHN-IU-2013-7258. St. 17, 3 males TL 12-18.5 mm, MNHN-IU-2013-7249, 1 male TL $13.5 \mathrm{~mm}, 1$ female TL $15.5 \mathrm{~mm}$, MNHN-IU-2013-7253. St. 22, 2 males TL 15.6, $19.5 \mathrm{~mm}, 3$ females TL 11.0-19.5 mm, MNHN-IU-2013-7254. St. 23, 2 males TL 10.7, 14.4 mm, 2 females TL 15.6, 19.5 mm, MNHN-IU-2013-7257. St. 25, 1 male TL 19.5 mm, 2 females 14.4, $15.3 \mathrm{~mm}$, MNHN-IU-2013-7252. St. 33, 1 male TL $17.3 \mathrm{~mm}, 1$ female TL 18.2 mm, MNHN-IU-2013-7256. St. 35, 1 male TL 21 mm, MNHN-IU-2013-7255.

DisTRIBUTION - Red Sea, Seychelles and Mayotte (first record) to Vietnam, Indonesia, Australia, Philippines, French Polynesia. Reef flat, to 60-80 m (in Ahyong, 2001).

REMARK - This is the commonest species collected during KUW 2009. It is a small species with TL reported between 17-38 mm (Manning, 1995; Ahyong, 2001). In largest male examined herein (TL $18.5 \mathrm{~mm}$ ) the aspect of the telson is as indicated in Manning (1995: 60): 'median and accessory median carinae are confluent posteriorly and appear as a single inflated median boss armed with three posterior spinules'. The aspect of the telson is, however, variable in G. affinis, as illustrated by Moosa and Cleva (1984, fig. 2) and Manning (1995, fig. 20). In fresh specimen the cornea is white, the body is pale red with white patches as illustrated in Figure 2A, white patches at basis of uropod and white posterior margin of somite 6 forming an continuous transverse white line. A similar color pattern is illustrated in Gosliner et al. (1996: 195) but these authors indicate that this species is "highly polymorphic in color ... individuals below 20 m often pink or red'.

\section{Gonodactylellus crosnieri (Manning, 1968)}

Gonodactylus crosnieri Manning, 1968: 48, fig. 15, Mayotte (Lagoon, 50 m, coll. A. Crosnier August 1959, paratypes 1 female TL 19.3 mm, USNM 124099, 1 female TL 13.5 mm, MNHN; also Madagascar Banc de Pracel, 50 m, muddy sand, coll. A. Crosnier June 1959, holotype 1 female TL 17.8 mm, USNM 124098).

DISTRIBUTION - Still known only from type material from Madagascar and Mayotte at $50 \mathrm{~m}$.

\section{Gonodactylellus lanchesteri (Manning, 1967)}

Gonodactylus lanchesteri Manning, 1967: 11 Mayotte, ('Mouniameri' = Monye Amiri - Islet between Mayotte and Pamanzi Islands, rocky lava and coral reef 0-4 m, coll. Taylor et al. November 23 1964, USNM 120292, 1 male, TL 21.9 mm) - Manning, 1968: 51, Mayotte, (Intertidal, coll. A. Crosnier, September 1959, 1 male TL 25.6 mm, USNM).

Distribution -WIO, Persian Gulf, Red Sea, Somalia, Kenya, Mozambique, South Africa, Mayotte, Madagascar, Pakistan. Also Vietnam (Manning, 1995). Intertidal to $60 \mathrm{~m}$ (in Müller, 1994). 


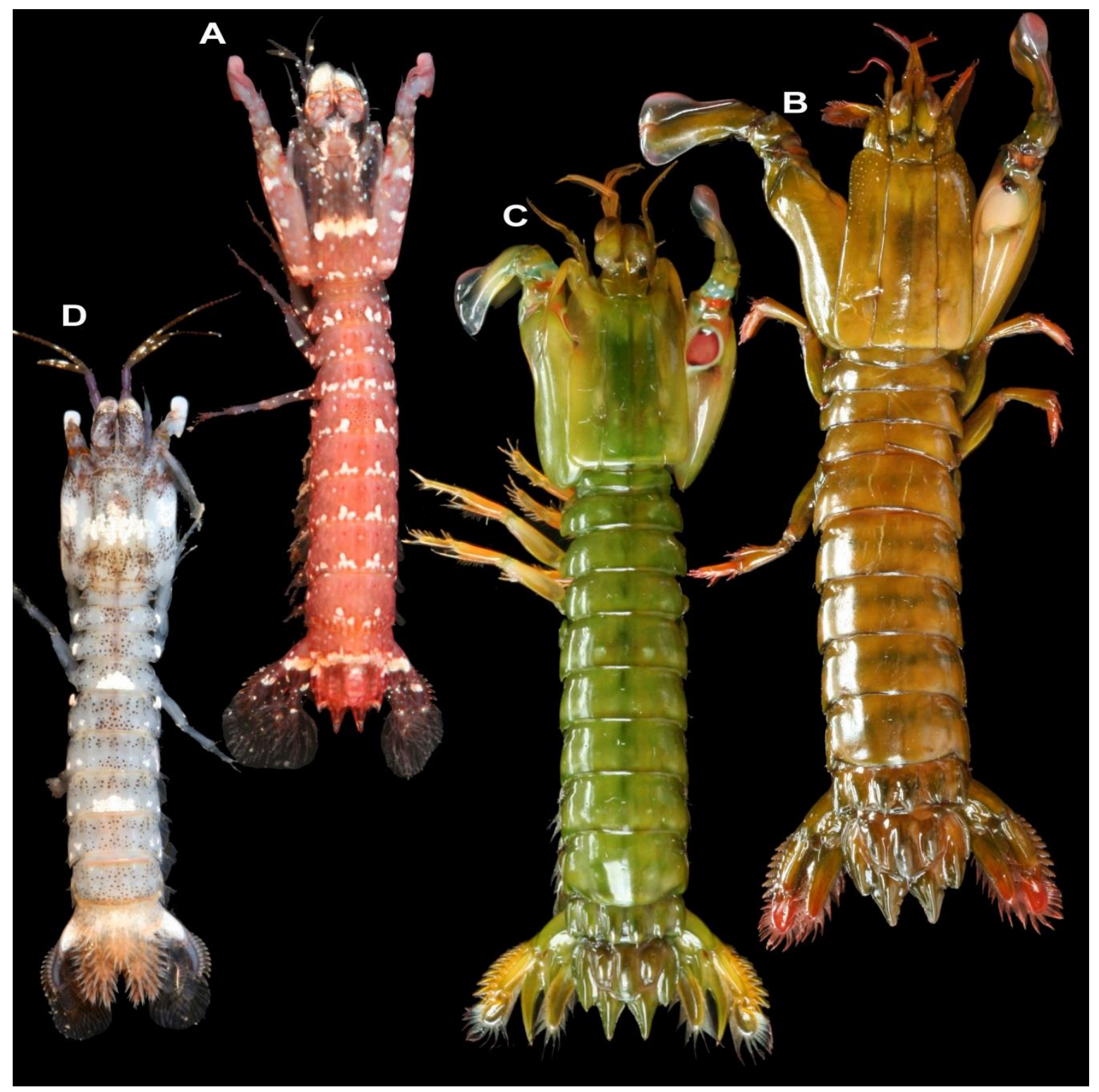

Figure 2. Color pattern of four stomatopods from Mayotte. A) Gonodactylellus affinis, 1 male TL 18.5 mm, MNHN-IU-2013-7249. B) Gonodactylus chiragra, 1 male TL 76.1 mm, MNHN-IU-2013-7244. C) Gonodactylus smithii, 1 male TL 46.9 mm, MNHN-IU-2013-7246. D) Chorisquilla spinosissima, 1 male, TL 15.7 mm, MNHN-IU-2013-7251.

Gonodactylus chiragra (Fabricius, 1781) (Figure 2B)

Gonodactylus chiragra - Fourmanoir, 1955: 33 (Comoros, 'commune dans les herbiers et coraux'). - Manning, 1968: 43, Mayotte (Reef, coll. L.S. Kornicker, sta LK-39, Anton Bruun Cruise 9, 24 November 1964, 1 male broken, TL 13.9 mm, USNM).

MATERIAL EXAMINED - Mission KUW November 2009. St. 26, 2 males TL 67.7, $76.1 \mathrm{~mm}$, MNHN-IU-2013-7244. St. 26, coll. J.-M. Bouchard 2008, 1 male TL 78.5 mm, MNHN-IU2013-7245. St. 29, 1 female TL 46.4 mm, MNHN-IU-2013-7247. 
DISTRIBUTION - Widely distributed in the IWP but exact range uncertain because 'virtually all members of Gonodactylus has been confused with G. chiragra at one time or another' (Manning, 1995). Persian Gulf, Red Sea, Mozambique, Comoros, Mayotte, Madagascar; Pakistan, Andaman Islands, Thailand, Vietnam, Indonesia, Australia, New Caledonia, Philippines, Japan, French Polynesia. Not listed from Hawaii in Ahyong (2002a). Intertidal to $2 \mathrm{~m}$.

REMARK - Fresh specimens (Figure 2B) have the characteristic red color on antennae, A2 scale, pereopods and uropods, as illustrated in Manning (1995, pl. 8). The white patch on the inside of the distal end of the merus of the claw is similar to that illustrated in Ahyong et al. (2008: fig. 11).

Gonodactylus platysoma Wood-Mason, 1895 (Figure 3A)

Gonodactylus platysoma - Manning, 1968: 44, Anjouan, Mayotte (Mayotte, intertidal, coll. A. Crosnier, September 1959, 1 male TL 72.8 mm, MNHN; Anjouan, intertidal, coll. A. Crosnier, November 1961, 1 male TL 59.7 mm, MNHN).

PhOtOGRAPH, SPECIMEN NOT COLLECTED - Mayotte, photo T. Mulochau, 21 August 2018, scuba

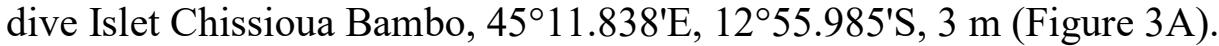

DisTRIBUTION - IWP, mainly on islands and atolls. Somalia, Comoros, Mayotte, Madagascar, Réunion, Mauritius, Maldives, Andaman, Thailand, Vietnam, Indonesia, Australia, New Caledonia, Philippines, Japan, Marshall Islands, French Polynesia. Not reported from Hawaii in Ahyong (2002a). Intertidal, shallow subtidal.

REMARK - A diagnostic character for G. platysoma is the spot bounded with dark blue on the eight thoracic somite and fifth abdominal somite.

Gonodactylus smithii Pocock, 1893 (Figure 2C)

Gonodactylus smithii - Manning, 1968: 44, Anjouan, Mayotte (Mayotte, reef, coll. L.S. Kornicker, St. LK-39, Anton Bruun Cruise I, 24 November 1964, 1 male TL 38.9 mm, USNM; Anjouan, intertidal, coll. A. Crosnier, November 1961, 1 female TL 29.4 mm, USNM).

MATERIAL EXAMINED - Mission KUW November 2009, St. 26, 1 male TL 46.9 mm, 2 females TL 37.8, 55.0 mm, MNHN-IU-2013-7246.

REMARK - The specimens examined have the characteristic red patch on the inside of the distal end of the merus of the claw (Figure 2C), also illustrated in Manning (1995, pl. 12).

DisTRIBUTION - IWP. Somalia, Comoros, Mayotte, Madagascar, Réunion, Mauritius, South Africa, Persian Gulf, Pakistan, Thailand, Vietnam, Indonesia, Australia, New Caledonia, Philippines, Japan, Marshall. Reported in Society Islands (Gosliner et al., 1996) but not in Hawaii (Ahyong, 2002a). Intertidal to $80 \mathrm{~m}$. 


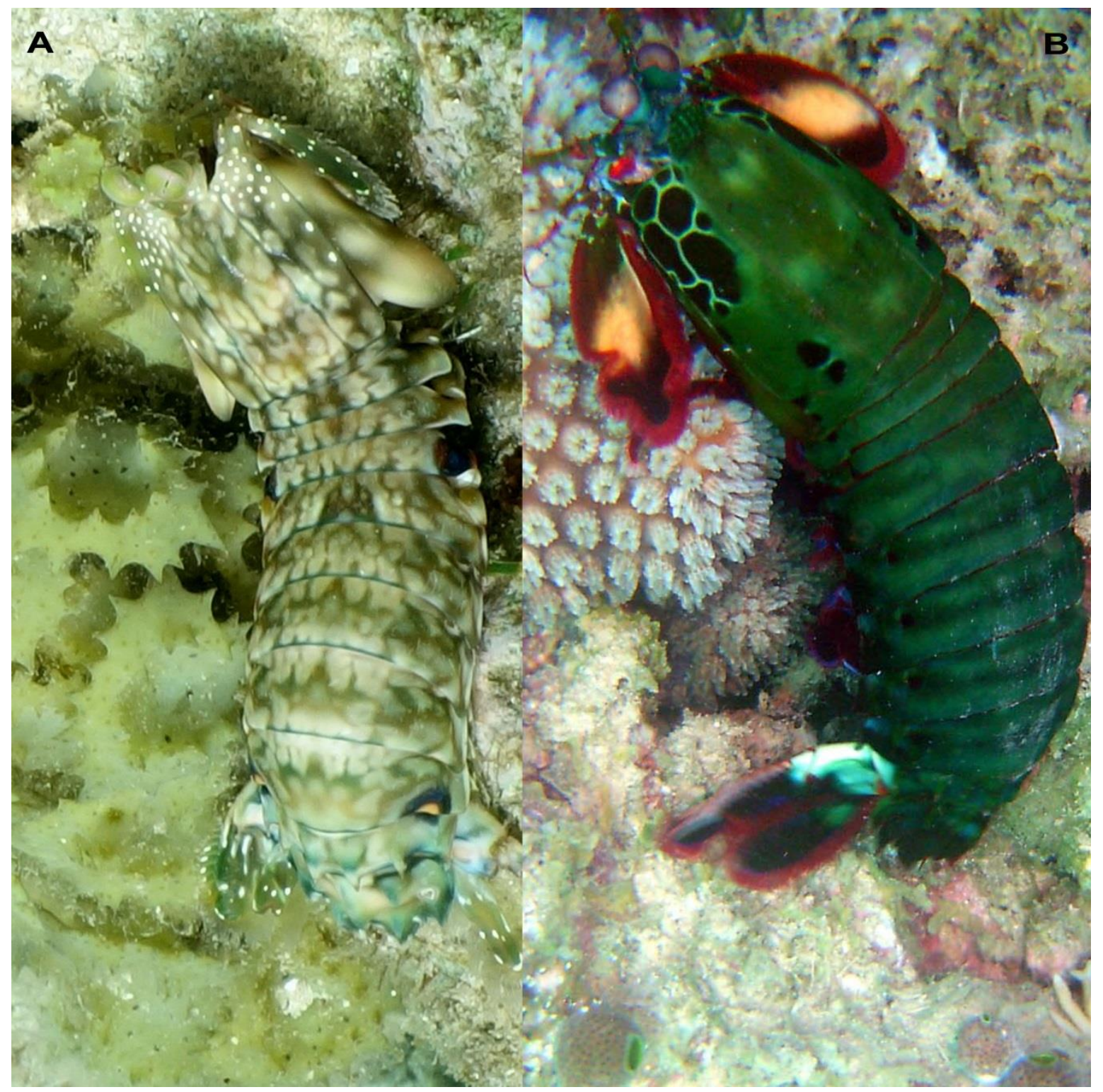

Figure 3. Two large stomatopods recognized during scuba dives at Mayotte. A) Gonodactylus platysoma, photo T. Mulochau, 21 August 2018, scuba dive Islet Chissioua Bambo, 45⒒838'E, 12 ${ }^{\circ} 55.985^{\prime} \mathrm{S}, 3 \mathrm{~m}$. B) Odontodactylus scyllarus, photo Claude Philippon, lagoon at night, 3-6 m.

\section{Family Odontodactylidae Manning, 1980}

Odontodactylus scyllarus (Linnaeus, 1758) (Figure 3B)

PhOTOGRAPHS, SPECIMENS NOT COLLECTED - Mayotte, several in situ photographs. Mission

KUW November 2009, St. 28, photo J. Dumas; Reef Boa Sadia, northwest, near islet Choizil, 3 September 2009, 20 m, photo M. Deuss; Mayotte lagoon several photos at night, C.

Philippon (Figure 3B), M. Allaria, and B. Pineau.

DisTRIBUTION - IWP. Kenya, Tanzania, Mozambique, Seychelles, Mayotte (first record), Madagascar, Réunion, Mauritius, Thailand, Vietnam, Indonesia, Philippines, Japan, Australia, 
New Caledonia, Papua New Guinea, Fiji, American Samoa. Not reported from French Polynesia and Hawaii. Low intertidal to $72 \mathrm{~m}$.

REMARK - This species can be easily recognized in in-situ photographs. Anterolateral and sometimes posterolateral areas of carapace have large dark brown spots outlined in white (Figure 3B; Manning, 1995, pl. 13; Ahyong et al., 2008, fig. 22).

\section{Family Protosquillidae Manning, 1980}

Chorisquilla spinosissima (Pfeffer, 1888) (Figure 2D)

MATERIAL EXAMINED - Mission KUW November 2009. St. 14, 1 male TL 17.5 mm, MNHN-IU2013-7259. St. 17, 1 male, TL 15.7 mm, MNHN-IU-2013-7251.

DISTRIBUTION - Mostly IO but exact range uncertain because confusion with Chorisquilla hystrix (Nobili, 1899). Red Sea, Somalia, Kenya, Mayotte (first record), Madagascar, Sri Lanka, South China Sea. According to Ahyong (2001): 'C. hystrix and C. spinosissima are so similar that they could prove to be eastern and western populations of a single widespread Indo-West Pacific species ... Chorisquilla hystrix appears to be primarily a Pacific species and C. spinosissima is primarily an Indian Ocean species'. Reef flat to $22 \mathrm{~m}$ (this work, Mayotte KUW 2009, St. 17).

REMARK - This species is affiliated to Chorisquilla hystrix (Nobili, 1899) formerly considered as a junior synonym. Ahyong (2001) has compared the two species and provided key characters to separate them. The specimens examined from Mayotte have: a) AS5 with mid-dorsal surface smooth (bearing longitudinal carinae on posterior $1 / 2$ to $1 / 3$ in C. hystrix); b) AS4-5 smooth (with carinae/spines in C. hystrix); and c) body almost uniformly pigmented (see Figure 2D) (banded in C. hystrix). Ahyong \& Erdmann (2003) must be consulted for more comments on these two species and the description of a third related species, Chorisquilla kroppi Ahyong \& Erdmann, 2003, still known only from Guam.

\section{Family Pseudosquillidae Manning, 1977}

\section{Pseudosquilla ciliata (Fabricius, 1787)}

Pseudosquilla ciliata - Fourmanoir, 1955: 33, Comoros. - Manning, 1968: 42, Anjouan, Mayotte (Anjouan, in trevally stomach, coll. A. Crosnier, 1 female TL $63.8 \mathrm{~mm}$, MNHN; Mayotte, $47 \mathrm{~m}$, sand, coll. A. Crosnier, August 1959, 1 post larvae TL $17.9 \mathrm{~mm}, \mathrm{MNHN}$; Mayotte, $51 \mathrm{~m}$, coarse sand, coll. A. Crosnier, 1 October 1959, 1 female TL $20.0 \mathrm{~mm}$, MNHN).

MATERIAl eXAmined - Mission KUW November 2009. St. 31, 3 females TL 19.0-20.0 mm, MNHN-IU-2013-7250.

DiSTRIBUTION - Pantropical, but not Eastern Pacific. In the IWP, Persian Gulf, Red Sea, Somalia, Mozambique, Seychelles, Comoros, Mayotte, Madagascar, Réunion, Mauritius, Sri Lanka, Vietnam, Indonesia, Australia, New Caledonia, Papua New Guinea; Philippines, Hawaii, French Polynesia. Intertidal to $110 \mathrm{~m}$. Fourmanoir (1955) indicates that the species is probably more common in deep water 'Cette variété doit vivre en eau profonde, nous en avons trouvé deux exemplaires dans l'estomac de Blepharis sp. qui ne s'aventure pas dans la zone intercotidale'. Mayotte specimens were collected by A. Crosnier at 47-51 m.

REMARK - Two of the 3 specimens examined from Mayotte have faint remains of lateral black patches on sixth thoracic sternite (TS6) and first abdominal tergite (AS1) and a dorso median 
patch on TS7. This color pattern is also indicated by Fourmanoir (1955) for Comoros specimens 'Une tache noire de chaque côté du sixième segment thoracique (TS6) et du premier segment abdominal (AS1)'. This form is the 'forme claire' of Serène (1951) illustrated in Manning (1995, pl. 20). Manning (1995) has indicated that all specimens examined from Mayotte correspond to this 'forme claire'.

\section{Pseudosquillana richeri (Moosa, 1991)}

Pseudosquilla richeri - Ahyong et al., 2000: 306, Comoros (poison station, 1240'23"S, $045^{\circ} 04^{\prime} 28^{\prime \prime} \mathrm{E}=$ North of Mayotte, in front of Mtsahara, 6-18 m, stn RW88-15, call. R. Winterbottom, 15 Nov.1988, 1 male TL 39 mm, 3 females 16-41 mm, USNM 268582).

DiSTRIBUTION - IWP, widely distributed, Red Sea, Mozambique channel, Comoros (Mayotte), Seychelles, Indonesia, Australia, Japan, Philippines, Papua New Guinea, Solomon, New Caledonia, Vanuatu, Fiji, Caroline, Kiribati, Marshall, Samoa, French Polynesia. Shore to 62 m (Ahyong et al., 2000).

\section{Superfamily Squilloidea Latreille, 1802}

\section{Family Squillidae Latreille, 1802}

\section{Fallosquilla fallax (Bouvier, 1914)}

Clorida fallax - Manning, 1968: 8, Mayotte (Lagoon, 1 male broken TL 5.6 mm, coll. A. Crosnier August 1959, USNM).

Distribution- Red Sea, Mayotte, Mauritius, Vietnam, Indonesia, Australia, New Caledonia, Solomon Islands. Shallow water to $78 \mathrm{~m}$ (in Ahyong, 2001)

\section{Neoanchisquilla tuberculata Ahyong, 1998}

Neoanchisquilla tuberculata Ahyong, 1998: 224, Anjouan (Holotype USNM 260879, male TL 74 mm, Comoros, 12¹1'09"S 4419'03"E, Anjouan Island, 9-20 m, RW88-26, coll. R. Winterbottom, 21 November 1988).

DisTRIBUTION -Only Comoro Islands and the Marquesas, 9-108 m (adults or subadults) to 800 $\mathrm{m}$ (larvae and postlarvae), in Ahyong (2002b), with this remark 'The remarkably discontinuous distribution likely reflects inadequate sampling effort in intermediate localities'.

\section{DISCUSSION}

The richness of Mayotte stomatopod fauna is compared with other places in the IWP in Table 1. The figures presented appear biased by non-homogeneous sampling efforts and/or regional studies. The richness is greater for Australia (152 spp.) which has benefited from a major contribution by Ahyong (2001). Others places rather well studied are New Caledonia, Vietnam, and Taiwan with ca. 70-90 species. Sampling effort is still probably insufficient in other places of Table 1 although the low figures for Cocos Keeling, Christmas Islands (13 spp.) and Hawaii (20 spp.) reflect probably an impoverished fauna because of, respectively, a limited geographical area and geographical isolation in central Pacific.

In the case of Comoros and Mayotte it is likely that some of the 30 species reported from nearby Madagascar are also in Mayotte. These are for example the species collected on the 'Banc du Pracel', situated approximately $500 \mathrm{~km}$ south of Mayotte between Madagascar and Juan de Nova Island, reported 
by Manning $(1968,1978)$ with synonymy and corrections in Ahyong (2001): Carinosquilla spinosa Ahyong and Naiyanetr, 2002 (as Squilla carinata Serène, 1950 in Manning, 1968); Cloridina chlorida (Brooks, 1886); Harpiosquilla melanoura Manning, 1968; Neclorida miersi (Manning, 1968);

Quollastria subtilis (Manning, 1978) (as Squilla gonypetes Kemp, 1911 in Manning, 1968). When this fauna is better studied in the vast lagoon of Mayotte Island, which is the largest in the Indian Ocean $\left(1100 \mathrm{~km}^{2}\right)$, the biodiversity could be expected to reach to at least 30-40 species and probably much more.

Table 1. Stomatopod richness of species in several IWP localities

\begin{tabular}{|l|c|l|}
\hline Place & $\begin{array}{c}\text { Number of } \\
\text { stomatopods }\end{array}$ & \multicolumn{1}{|c|}{ References } \\
\hline Cocos Keeling, Christmas Islands & 13 & Ahyong (2014) \\
\hline Comoros and Mayotte & 14 & This study \\
\hline Somalia & 17 & Cappola \& Manning (1994) \\
\hline Réunion & 17 & $\begin{array}{l}13 \text { spp. in Poupin (2009), updated to 17 spp. from field } \\
\text { observations in Legall \& Poupin (2019) }\end{array}$ \\
\hline Hawaii & 20 & Ahyong (2002a) \\
\hline Madagascar & 30 & Manning (1968, 1970a, b, 1978) \\
\hline French Polynesia & 45 & $\begin{array}{l}37 \text { spp. in Ahyong (2002b), plus 7 spp. in Ahyong (2017), } \\
\text { plus 1 sp. in Ahyong \& Caldwell (2017) }\end{array}$ \\
\hline Taiwan & 66 & $\begin{array}{l}63 \text { spp. in Ahyong et al. (2008); plus 3 spp. in Wang \& } \\
\text { Chiou (2017). }\end{array}$ \\
\hline Vietnam & 72 & Manning (1995) \\
\hline New Caledonia & 152 & $\begin{array}{l}\text { 62 spp (0-100 m depth range) in Ahyong (2007) updated to } \\
90 \text { spp. in Legall \& Poupin (2019) }\end{array}$ \\
\hline Australia & \begin{tabular}{l} 
Ahyong (2001); Ahyong (2008); Ahyong \& Wassenberg \\
\hline
\end{tabular}
\end{tabular}

\section{ACKNOWLEDGMENTS}

Financial support for this study has been obtained from the Direction de l'Agriculture et de la Forêt of Mayotte (DAF) and Total Foundation. Supplementary assistance for this research has been given by the École Navale, Brest and the Muséum national d'Histoire naturelle, Paris (MNHN). Photographs of species with living coloration were obtained via some collaborators, by alphabetical order: Marc Allaria, Matthias Deuss, Yvon Gildas, J. -B. Nicet, Claude Philippon, Benjamin Pineau, Norbert Verneau and T. Mulocheau. S. Ahyong has helped for determination of G. ternatensis and has also made appreciated comments and corrections on the submitted manuscript. A second anonymous reviewer has also contributed to improve the manuscript. 


\section{REFERENCES}

Ahyong, S. T. 1998. Review of Neoanchisquilla Moosa, 1991 and Neclorida Manning, 1995 (Crustacea: Stomatopoda: Squilloidea), with descriptions of two new species of Neoanchisquilla from the Indian Ocean. Records of the Australian Museum, 50(2), 217-229. At https://journals.australianmuseum.net.au/ahyong-1998-rec-aust-mus-502-217229/

Ahyong, S. T. 2001. Revision of the Australian Stomatopod Crustacea. Records of the Australian Museum, supplement 26, 1-326. At https://journals.australianmuseum.net.au/ahyong-2001-rec-aust-mus-suppl-26-1326/

Ahyong, S. T. 2002a. A new species and new records of stomatopoda from Hawaii. Crustaceana, 75(6), 827-840. At https://www.jstor.org/stable/20105463?seq=1\#page_scan_tab_contents

Ahyong, S. T. 2002b. Stomatopoda (Crustacea) from the Marquesas Islands: results of the MUSORSTOM 9. Zoosystema, 24(2), 347-372. At http://sciencepress.mnhn.fr/sites/default/files/articles/pdf/z2002n2a7.pdf

Ahyong, S. T. 2007. Shallow water Stomatopoda of New Caledonia (0-100 m). In: Payri C.E. and B. Richer de Forges (eds) Compendium of marine species of New Caledonia. Documentation Scientifique et Technique du centre IRD Nouméa, II(7), 333-335. At http://horizon.documentation.ird.fr/exl-doc/pleins_textes/divers15-05/010059819.pdf

Ahyong, S. T., 2008. Stomatopod Crustacea of the Dampier Archipelago, Western Australia. Records of the Western Australian Museum, 73, 41-55 [Dated 2007, published 2008]. At http://museum.wa.gov.au/sites/default/files/4.\%20Ahyong.pdf

Ahyong, S. T. 2014. Stomatopod Crustacea of Christmas Island and the Cocos (Keeling) Islands. Raffles Bulletin of Zoology, supplement 30, 246-254. At https://1kcnhm.nus.edu.sg/rbz/supplement-no-30/

Ahyong, S. T. 2017. Stomatopod Crustacea of the Austral and Gambier Islands, French Polynesia. Zootaxa, 4286(4), 555-564. At http://dx.doi.org/10.11646/zootaxa.4286.4.8

Ahyong, S. T., and R. L. Caldwell. 2017. The mantis shrimps of the genus, Raoulserenea Manning, 1995 (Crustacea: Stomatopoda: Pseudosquillidae) from French Polynesia, with description of a new species and notes on its reproduction. Journal of Crustacean Biology, 37(5), 608-614. At https://doi.org/10.1093/jcbiol/rux060

Ahyong, S. T., and M. V. Erdmann. 2003. The stomatopod Crustacea of Guam. Micronesica, 35-36, 315-352. At http://micronesica.org/sites/default/files/17-stomatopods_0.pdf

Ahyong, S. T., and P. Naiyanetr. 2002. Stomatopod crustaceans from Phuket and the Andaman Sea. In: Proceedings of the International Workshop on the Crustacea of the Andaman Sea, Phuket Marine Biological Center, Department of Fisheries, Thailand, 29 November - 20 December 1998. Phuket Marine Biological Center Special Publication, 23(2), 281-312.

Ahyong, S. T. and T. J. Wassenberg. 2015. The rare mantis shrimp Areosquilla indica (Hansen, 1976) (Crustacea, Stomatopoda) from the Great Barrier Reef: first Australian records of the genus and species. Zootaxa, 4000(4), 492-496. At http://dx.doi.org/10.11646/zootaxa.4000.4.8 
Ahyong, S. T., T. -Y. Chan, and Y. -C. Liao. 2008. A catalog of the mantis shrimps (Stomatopoda) of Taiwan. National Taiwan Ocean University, Keelung, 1-190. At http://www.vliz.be/imisdocs/publications/ocrd/245752.pdf

Ahyong, S. T., R. B. Manning, and K. Reed. 2000. Revision of Pseudosquillana Cappola \& Manning, 1995 (Crustacea: Stomatopoda: Pseudosquillidae). Raffles Bulletin of Zoology, 48(2), 301-311.

Bouchard, J. -M., J. Poupin, R. Cleva, J. Dumas, and V. Dinhut. 2013. Land, mangrove and freshwater decapod crustaceans of Mayotte region (Crustacea, Decapoda). Atoll Research Bulletin, 592: 169. At http://opensi.si.edu/index.php/smithsonian/catalog/book/33

Cappola, V. and R. B. Manning. 1995. Crustacea stomatopoda. Research on the coast of Somalia. Tropical Zoology, 1994 (1995), 7(2), 271-291. At https://doi.org/10.1080/03946975.1994.10539258

Fourmanoir, P. 1955. Crustacés Macroures et Anomoures, Stomatopodes. Notes sur la faune intercotidale des Comores. Le Naturaliste Malgache, 7(1), 19-33. At http://horizon.documentation.ird.fr/exl-doc/pleins textes/pleins textes 5/b fdi 10-11/11450.pdf

Gosliner, T. M., D. W. Behrens, and G. C. Williams. 1996. Coral reef animals of the Indo-Pacific. Animal life from Africa to Hawai'i, exclusive of the vertebrates. Sea Challengers, Monterey, California, $1-314$.

Legall, N., and J. Poupin. 2019. CRUSTA: Database of Crustacea (Decapoda and Stomatopoda), with special interest for those collected in French overseas territories. At http://crustiesfroverseas.free.fr/

Manning, R. B. 1967. Notes on the demanii section of the genus Gonodactylus Berthold, with descriptions of three new species (Crustacea, Stomatopoda). Proceedings of the United States National Museum, 123(3618), 1-27. At https://doi.org/10.5479/si.00963801.123-3618.1

Manning, R. B., 1968. Stomatopod Crustacea from Madagascar. Proceedings of the United States National Museum, 124(3641), 1-61. At https://doi.org/10.5479/si.00963801.124-3641.1

Manning, R. B. 1970a. Some stomatopod crustaceans from Tuléar, Madagascar. Bulletin du Muséum national d'Histoire naturelle, 41(6), 1429-1441. At https://archive.org/details/bulletindumuseu41musea/page/1428

Manning, R. B. 1970b. A new genus and species of Stomatopod crustacean from Madagascar. Bulletin du Muséum national d'Histoire naturelle, 42(1), 206-209. At https://archive.org/details/bulletindumuseu42musea/page/206

Manning, R. B. 1978. Further observations on Oratosquilla, with accounts of two new genera and nine new species (Crustacea, Stomatopoda, Squillidae). Smithsonian Contribution to Zoology, 272, 1 44. At https://doi.org/10.5479/si.00810282.272

Manning, R. B. 1995. Stomatopod Crustacea of Vietnam: The legacy of Raoul Serène. Crustacean Research, special number 4, 1-339. At https://doi.org/10.18353/crustacea.Special1995.4_1

Moosa, M. K., and R. Cleva. 1984. Sur une collection de stomatopodes (Crustacea, Hoplocarida) provenant des îles Seychelles. Bulletin du Muséum national d'Histoire naturelle, Paris, 6(2), 421429.

Müller, H. G. 1994. World catalogue and bibliography of the recent Stomatopoda. Wissenschaftler Verlag, Laboratory for Tropical Ecosystems, Research and Information Service, P.O. Box 2268, D-25532, Wetzlar, Germany, 1-288.

Poupin, J. 2009. Crustacés de la Réunion, Décapodes et Stomatopodes. IRD Editions, Marseille, 140 pp. At http://horizon.documentation.ird.fr/exl-doc/pleins textes/ed-09-10/010050352.pdf 
Poupin, J. 2016. First inventory of the Crustacea (Decapoda, Stomatopoda) of Juan de Nova Island with ecological observations and comparison with nearby islands in the Mozambique Channel (Europa, Glorieuses, Mayotte). Acta Oecologica, 72, 41-52. At https://doi.org/10.1016/j.actao.2015.04.001

Poupin, J., J. -M. Bouchard, V. Dinhut, R. Cleva, and J. Dumas. 2013. Anomura of Mayotte region (Crustacea Decapoda). Atoll Research Bulletin, 593: 1-73. At

http://opensi.si.edu/index.php/smithsonian/catalog/book/35

Poupin, J., R. Cleva, J. -M. Bouchard, V. Dinhut, and J. Dumas. 2018. The crabs from Mayotte Island (Crustacea, Decapoda, Brachyura). Atoll Research Bulletin, 617, i-vi, 1-109. At http://doi.org/10.5479/si.0077-5630.617

Serène, R. 1951. Observations sur deux Pseudosquilla d'Indochine. Treubia, 21(1), 11-25. At http://e-journal.biologi.lipi.go.id/index.php/treubia/article/view/2643

Wang, J. W. and T. H. Chiou. 2017. Three new records of Nannosquillidae from Taiwan with notes on their ecology (Crustacea, Stomatopoda, Lysiosquilloidea). ZooKeys, 721, 33-43. At https://doi.org/10.3897/zookeys.721.20588 